\title{
Synthesis of 2-amino-3-arylpropan-1-ols and 1-(2,3-diaminopropyl)-1,2,3-triazoles and evaluation of their antimalarial activity
}

\author{
Matthias D'hooghe ${ }^{* 1}$, Stéphanie Vandekerckhove ${ }^{1}$, Karen Mollet ${ }^{1, \S}$, \\ Karel Vervisch $^{1}$, Stijn Dekeukeleire ${ }^{1, \S}$, Liesbeth Lehoucq ${ }^{1}$, \\ Carmen Lategan ${ }^{2}$, Peter J. Smith ${ }^{2}$, Kelly Chibale ${ }^{3}$ and Norbert De Kimpe ${ }^{* 1}$
}

\section{Full Research Paper}

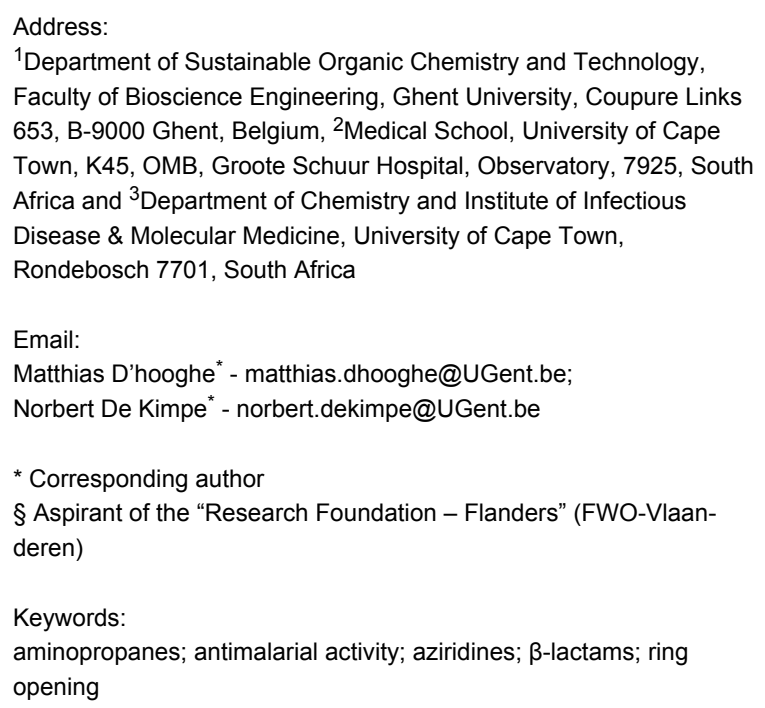

${ }^{1}$ Department of Sustainable Organic Chemistry and Technology, Faculty of Bioscience Engineering, Ghent University, Coupure Links 653, B-9000 Ghent, Belgium, ${ }^{2}$ Medical School, University of Cape Town, K45, OMB, Groote Schuur Hospital, Observatory, 7925, South Africa and ${ }^{3}$ Department of Chemistry and Institute of Infectious Disease \& Molecular Medicine, University of Cape Town, Rondebosch 7701, South Africa

Email:

Matthias D'hooghe* - matthias.dhooghe@UGent.be;

Norbert De Kimpe* - norbert.dekimpe@UGent.be

* Corresponding author

$\S$ Aspirant of the "Research Foundation - Flanders" (FWO-Vlaanderen)

Keywords:

aminopropanes; antimalarial activity; aziridines; $\beta$-lactams; ring opening

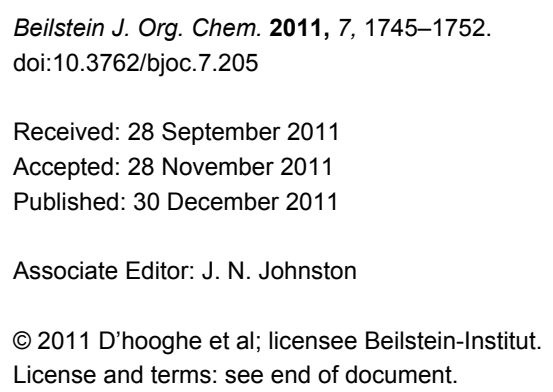

\begin{abstract}
A variety of 2-amino-3-arylpropan-1-ols, anti-2-amino-3-aryl-3-methoxypropan-1-ols and anti-2-amino-1-arylpropan-1,3-diols were prepared selectively through elaboration of trans-4-aryl-3-chloro- $\beta$-lactams. In addition, a number of 2-(azidomethyl)aziridines was converted into novel 2-[(1,2,3-triazol-1-yl)methyl]aziridines by $\mathrm{Cu}(\mathrm{I})$-catalyzed azide-alkyne cycloaddition, followed by microwave-assisted, regioselective ring opening by dialkylamine towards 1-(2,3-diaminopropyl)-1,2,3-triazoles. Although most of these compounds exhibited weak antiplasmodial activity, six representatives showed moderate antiplasmodial activity against both a chloroquine-sensitive and a chloroquine-resistant strain of Plasmodium falciparum with $\mathrm{IC}_{50}$-values of $\leq 25 \mu \mathrm{M}$.
\end{abstract}

\section{Introduction}

Malaria remains a major issue in health control, especially in developing countries. This disease affects $40 \%$ of the global population, causing an annual mortality of one million people
[1]. Despite recent advances in the development of a vaccine against malaria, chemotherapy remains the most viable alternative towards treatment of the disease [2]. In light of the rapid 
emergence of multiple drug resistance to clinically established antimalarial drugs, however, there is a compelling need to introduce new chemicals that can overcome this resistance. In 2007, nitrogen-analogues of glycerol, which have a long-standing tradition in medicine as $\beta$-blockers, were introduced as a novel class of antimalarials [3]. Prior to this, the well known $\beta$-blocker propranolol was shown to inhibit infection of erythrocytes by $P$. falciparum, as well as to reduce the parasitaemia of $P$. berghei infections in vivo [4,5]. In light of the biological potential of these compounds, continuous efforts have been devoted to the preparation of structurally diverse analogues bearing a functionalized propane skeleton [6-8]. In that respect, we have been engaged in the stereoselective synthesis of syn-2alkoxy-3-amino-3-arylpropan-1-ols 1 by reductive ring opening of the corresponding $\beta$-lactams, which were shown to be of great importance as novel antiplasmodial agents (Figure 1) [6]. More recently, we reported 1,2,3-triaminopropanes $\mathbf{2}$ as a new class of antimalarial compounds (Figure 1), prepared through microwave-assisted, regioselective ring opening of the corresponding 2-(aminomethyl)aziridines by diethylamine [8]. Nonetheless, a number of challenges with regard to structure-activity relationship studies of functionalized aminopropanes remain unaddressed, especially concerning the screening of structural analogues of aminopropanes $\mathbf{1}$ and $\mathbf{2}$.

In the present paper, the synthesis of racemic anti-2-aminopropan-1-ols 3 is described as a variant of the syn-3-aminopropan-1-ols 1 synthesis (regio- and stereoisomerism with respect to the relative position of the amino group $\mathrm{NHR}^{2}$ and the oxygen substituent $\mathrm{OR}^{3}$, Figure 1), by applying a different synthetic route. Furthermore, a new synthetic approach is disclosed towards racemic aminopropanes 4 bearing a 1,2,3triazole moiety, as structural analogues of the previously reported 1,2,4-triazoles 2 (Figure 1). Both classes of functionalized aminopropanes $\mathbf{3}$ and $\mathbf{4}$ were tested for their antiplasmodial activity.

\section{Results and Discussion Synthesis}

Within azaheterocyclic chemistry, aziridines [9-17] and $\beta$-lactams [18-27] are extraordinary classes of strained com- pounds with diverse synthetic and biological applications. In previous works, we have elaborated the synthetic potential of 3-chloroazetidin-2-ones with a focus on stereoselectivity, thus providing convenient entries into, e.g., aziridines, azetidines and $\beta$-aminoalcohols [28-31]. In continuation of our interest in the use of functionalized $\beta$-lactams as synthons for further elaboration, racemic trans-4-aryl-3-chloro- $\beta$-lactams 5 were prepared by treatment of $N$-(arylmethylidene)alkylamines (synthesized in high yields through condensation of the corresponding benzaldehydes with the appropriate primary amines in $\mathrm{CH}_{2} \mathrm{Cl}_{2}$ in the presence of anhydrous $\mathrm{MgSO}_{4}$ ) with 1.5 equiv of chloroacetyl chloride and 3 equiv of 2,6-lutidine in benzene according to a literature protocol [30]. Subsequently, $\beta$-lactams 5 were subjected to $\mathrm{LiAlH}_{4}$-mediated reductive ring opening, furnishing either 2-aminopropan-1-ols $\mathbf{6 a - c}$, by using two molar equiv of $\mathrm{LiAlH}_{4}$ in $\mathrm{Et}_{2} \mathrm{O}$ under reflux for $20-80 \mathrm{~h}$, or trans-2aryl-3-(hydroxymethyl)aziridines $\mathbf{7} \mathbf{a}-\mathbf{h}$ by applying milder reactions conditions (i.e., one molar equiv of $\mathrm{LiAlH}_{4}$ in $\mathrm{Et}_{2} \mathrm{O}$ at room temperature for 5-8 h) (Scheme 1) [30].

As aziridines are known to be versatile synthetic intermediates for the preparation of a variety of ring-opened and ringexpanded amines, the aziridines 7 were deployed as substrates for the stereoselective synthesis of functionalized aminopropanols. In accordance with a literature approach [30], the nonactivated trans-2-aryl-3-(hydroxymethyl)aziridines 7 were regio- and stereoselectively converted into anti-2-amino-3-aryl3-methoxypropan-1-ols 8a-e through heating in methanol under reflux (Scheme 1). Furthermore, in order to provide access to the class of 2-aminopropan-1,3-diols, aziridines 7 were evaluated for the first time as substrates for a water-induced aziridine ring opening in an acidic medium. Thus, treatment of trans-2-aryl-3-(hydroxymethyl)aziridines 7 with one equiv of para-toluenesulfonic acid in a $\mathrm{H}_{2} \mathrm{O} / \mathrm{THF}(1 / 1)$ solvent system [32] furnished novel anti-2-amino-1-arylpropan-1,3-diols 9a-d in good yields after $3 \mathrm{~h}$ at $40{ }^{\circ} \mathrm{C}$, again in a regio- and stereospecific way (Scheme 1). The observed regio- and stereoselectivity in aminopropanols 8 and $\mathbf{9}$ can be rationalized by considering the ring opening of the aziridine moiety at $\mathrm{C} 2$ due to benzylic stabilization of the developing carbenium ion in an $\mathrm{S}_{\mathrm{N}} 2$ fashion [30].

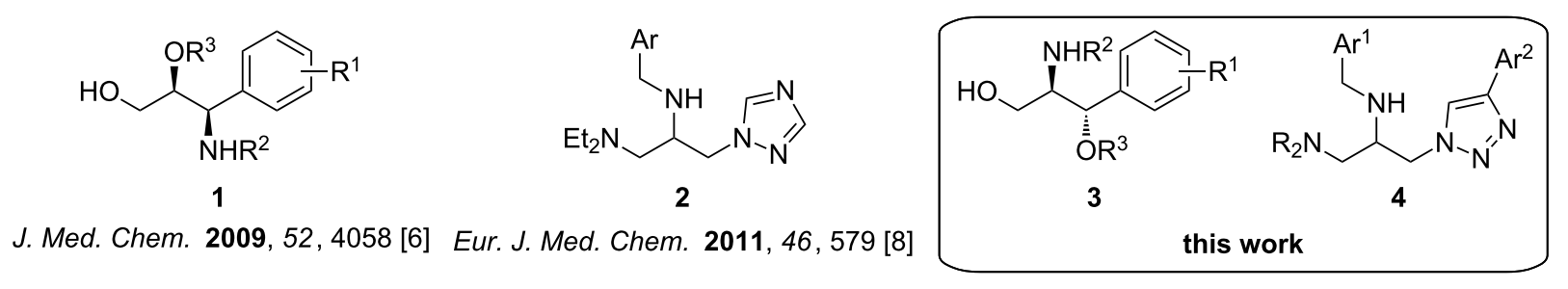




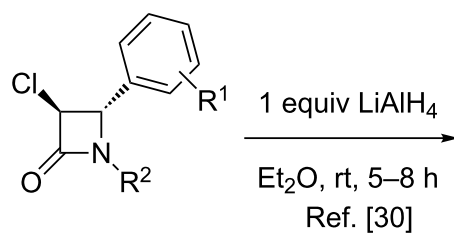

$5 a-h$<smiles>[R][R]1cccc([C@@H]2[C@H](CO)N2[R])c1</smiles>

7a-h (33-91\%)

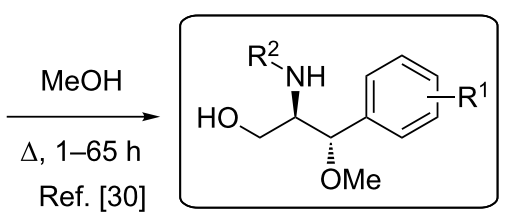

$8 \mathbf{a}-\mathbf{e}(38-52 \%)$

$\mathrm{R}^{1}=\mathrm{H}, 4-\mathrm{Cl}, 4-\mathrm{OMe}, 2-\mathrm{F}$ $\mathrm{R}^{2}=\mathrm{iPr}, \mathrm{Bn}, \mathrm{iBu}, n-\mathrm{Pr}$

1 equiv $p$ - $\mathrm{TsOH}$

$\mathrm{H}_{2} \mathrm{O} / \mathrm{THF}(1 / 1)$

$40{ }^{\circ} \mathrm{C}, 3 \mathrm{~h}$

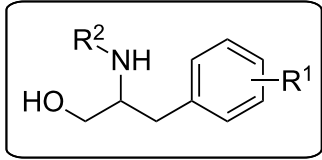

6a-c (37-60\%)

$\mathrm{R}^{1}=4-\mathrm{Cl}, 4-\mathrm{OMe}, 2-\mathrm{F}$

$\mathrm{R}^{2}=\mathrm{Bn}, \mathrm{iBu}, n-\mathrm{Pr}$

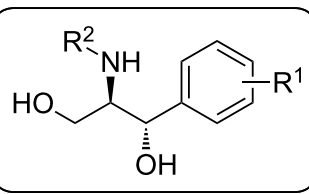

9a-d (55-95\%)

$\mathrm{R}^{1}=4-\mathrm{Cl}, 2-\mathrm{Cl}, 4-\mathrm{Me}, \mathrm{H}$

$\mathrm{R}^{2}=\mathrm{Bn}, 4-\mathrm{ClC}_{6} \mathrm{H}_{4} \mathrm{CH}_{2}$

Scheme 1: Synthesis of aminopropanols 6, 8 and 9.

As the use of imines bearing a $N$-tert-butyl group in combination with a substituent in the ortho-position of the aromatic ring is known to afford the corresponding cis-4-aryl-3-chloroazetidin-2-ones as the major stereoisomers after condensation with chloroketene in benzene [30], racemic cis-3-chloro- $\beta$ lactams 10a,b were prepared and converted into cis-2-aryl-3(hydroxymethyl)aziridines 11a,b upon treatment with two molar equiv of $\mathrm{LiAlH}_{4}$ in $\mathrm{Et}_{2} \mathrm{O}$ under reflux for $15 \mathrm{~h}$ (Scheme 2). Next, the aziridines 11, which have previously been shown to be unreactive towards $\mathrm{LiAlH}_{4}$ and methanol and thus unable to undergo ring opening [30], were used as substrates for a water-induced ring opening through initial protonation of the aziridine ring with $p$-TsOH. Although more drastic reaction conditions were required compared to the ring opening of trans-2-aryl-3-(hydroxymethyl)aziridines 7 ( 3 equiv $p$-TsOH, $\Delta, 30 \mathrm{~h}$ instead of 1 equiv $p$-TsOH, $40{ }^{\circ} \mathrm{C}, 3 \mathrm{~h}$ ), novel syn-aminopropanols 12a,, $\mathbf{b}$ were obtained in a selective and convenient way (Scheme 2, yields after purification), providing the first example of the ring opening of this type of aziridines. Also in this case, the observed regio- and stereoselectivity in the formation of aminopropanols $\mathbf{1 2}$ can be rationalized by considering the ring opening of the aziridine moiety at $\mathrm{C} 2$ due to benzylic stabilization of the developing carbenium ion in an $\mathrm{S}_{\mathrm{N}} 2$ fashion [30]. The formation of the other regio- and stereoisomers was excluded based on detailed spectroscopic analysis.

It should be noted that both diastereomeric antipodes of the class of 1-aryl-2-aminopropan-1,3-diols, i.e., anti- and synaminopropanols 9 and 12, can now be prepared selectively through choice of the appropriate imine for the Staudinger synthesis of the starting $\beta$-lactams.

Given the recently disclosed antiplasmodial activities of a number of 2,3-diamino-1-(1,2,4-triazol-1-yl)propanes [8], the second objective of this work was the preparation of new analogues bearing a 1,2,3-triazole moiety instead. A powerful methodology towards the synthesis of functionalized 1,2,3-tri-<smiles>[R1]c1ccccc1[C@@H]1[C@H](Cl)C(=O)N1C(C)(C)C</smiles><smiles>[R]c1ccccc1C1C(CO)N1C(C)(C)C</smiles3 equiv $p$ - $\mathrm{TsOH}$ $\mathrm{H}_{2} \mathrm{O} / \mathrm{THF}(1: 1)$ $\Delta, 30 \mathrm{~h}$

$11 a-b(53-55 \%)$

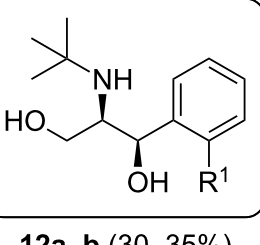

2a-b $(30-35 \%)$ $\mathrm{R}^{1}=\mathrm{OMe}, \mathrm{F}$ 
azoles involves the $\mathrm{Cu}(\mathrm{I})$-catalyzed azide-alkyne Huisgen cycloaddition (CuAAC) [33], which has gained major interest from the synthetic community due to its high efficiency and selectivity. Eligible substrates to perform "click chemistry" [34] incorporate an azide group and an aziridine ring in their structure, for example in 2-(azidomethyl)aziridines, thus providing a direct access to 2-[(1,2,3-triazol-1-yl)methyl]aziridines through $\mathrm{Cu}$-catalyzed reaction with alkynes [35].

In this work, nonactivated $N$-(arylmethyl)aziridines were selected as substrates, as previous research had revealed the importance of $N$-benzyl, $N$-chlorobenzyl and $N$-methoxybenzyl groups in functionalized aminopropanes with regard to their antiplasmodial activity [6,8]. Thus, a number of racemic 2-(azidomethyl)aziridines $\mathbf{1 4}$ was prepared by reaction of sodium azide with 2-(bromomethyl)aziridines 13 [36-38], employing the electrophilicity of the latter as a convenient handle for their connection to other moieties. In this way, novel 2-(azidomethyl)aziridines 14a-e were prepared in good yields by treatment of bromides $\mathbf{1 3}$ with two equiv of sodium azide in DMSO at $80{ }^{\circ} \mathrm{C}$ for $16 \mathrm{~h}$ (CAUTION) (Scheme 3). Subsequently, a CuI-catalyzed 1,3-cycloaddition of $N$-(arylmethyl)aziridine azides 14 was evaluated for the first time by utilizing one equiv of an arylacetylene in $\mathrm{CH}_{3} \mathrm{CN}$ under reflux for $16 \mathrm{~h}$, furnishing a direct entry towards new 2-[(1,2,3-triazol-1yl)methyl]aziridines $\mathbf{1 5 a}-\mathbf{f}$ in a highly efficient and selective way (Scheme 3).

The final step comprised ring opening of the aziridine moiety in compounds 15 by diethylamine to afford functionalized aminopropanes as potential antimalarial agents. With the intention to introduce a diethylamino group, a microwave-promoted ring opening of analogous aziridines by diethylamine with the aid of the $\mathrm{Et}_{2} \mathrm{NH} \cdot \mathrm{HCl} / \mathrm{Et}_{2} \mathrm{NH}$ system was employed [8]. In this way, protonation of the aziridine ring provides a highly electrophilic aziridinium intermediate, which is prone to undergo nucleophilic ring opening. In order to drive the reaction to completion, and to avoid competition between chloride- and diethylamine-induced ring opening, a large excess of $\mathrm{Et}_{2} \mathrm{NH} \cdot \mathrm{HCl}$ (20 equiv) and an additional amount of diethylamine (10 equiv) was used. Thus, heating of the aziridines 15 at $140{ }^{\circ} \mathrm{C}$ in $\mathrm{CH}_{3} \mathrm{CN}$ under microwave irradiation resulted in full and selective conversion to the desired new triaminopropanes $16 \mathbf{a}-\mathbf{e}$ after $2 \mathrm{~h}$ (Scheme 3), which were purified by column chromatography $\left(\mathrm{SiO}_{2}\right)$ in order to obtain analytically pure samples. Furthermore, in addition to the use of diethylamine, the introduction of a dimethylamino group was considered in order to compare the contribution of this moiety to the potential antiplasmodial activity with that of a diethylamino group. This objective was achieved by treatment of aziridines 15 with 20 equiv of $\mathrm{Me}_{2} \mathrm{NH} \cdot \mathrm{HCl}$ in $\mathrm{CH}_{3} \mathrm{CN}$ at $140{ }^{\circ} \mathrm{C}$ for $2 \mathrm{~h}$ under microwave irradiation, resulting in dimethylaminopropanes $\mathbf{1 6 f}, \mathbf{g}$ in good yields (Scheme 3). This result showed that this microwave-assisted methodology for the ring opening of nonactivated aziridines can be further extended towards the use of other secondary amines. In order to introduce structural diversity within these molecules, different substituent patterns at the aromatic rings $\left(\mathrm{R}^{1}, \mathrm{R}^{2}\right)$ in aminopropanes $16 \mathbf{a}-\mathrm{g}$ were realized as well.

In view of the biological potential of aminopropanes in general, compounds $6,8,9,12$ and 16 were subsequently screened for their antiplasmodial activity.

In addition, aziridines $\mathbf{1 4}$ and $\mathbf{1 5}$ were tested against the malaria parasite Plasmodium falciparum, too.

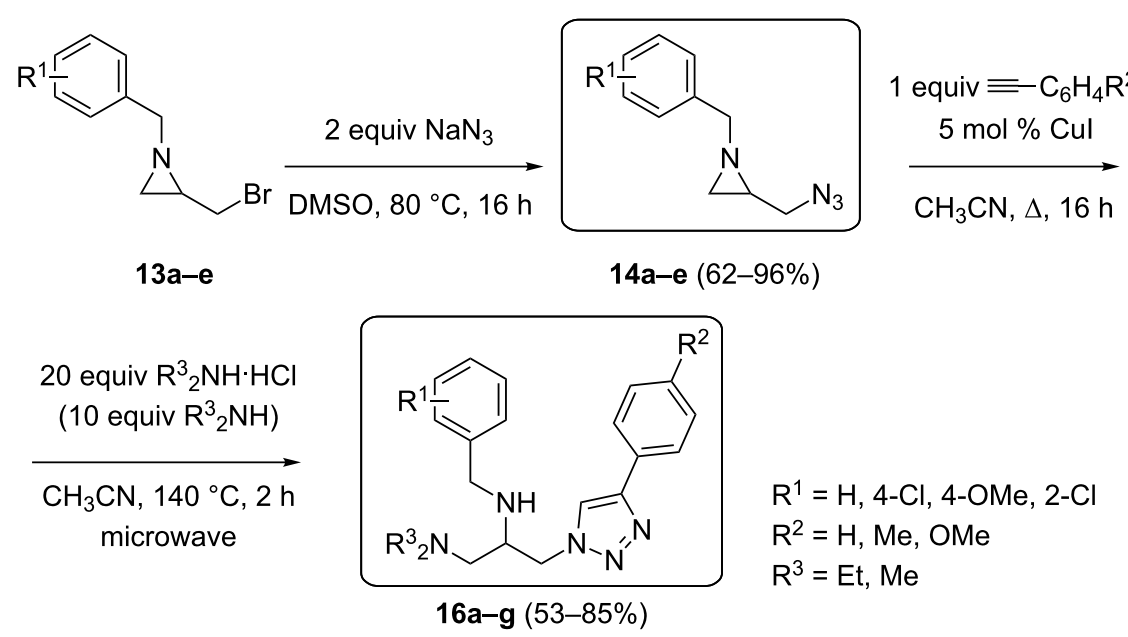

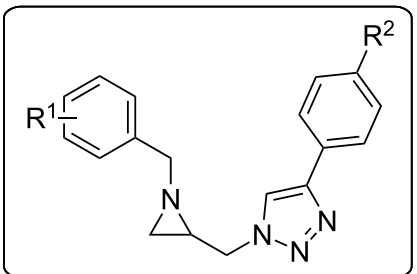

$15 a-f(58-84 \%)$ 


\section{Biological evaluation}

At first, compounds 6a-c, 8a-e, 9a-d, 12a,b, 14a-e, 15a-f and $16 \mathbf{a}-\mathbf{g}$ were screened for in vitro antiplasmodial activity. All samples were tested in triplicate on one occasion against a chloroquine-sensitive (CQS) strain of $P$. falciparum (D10). Those samples showing antiplasmodial activity were then tested in triplicate on one occasion against a chloroquine-resistant (CQR) strain of P. falciparum (Dd2) and screened for in vitro cytotoxicity against a Chinese hamster ovary $(\mathrm{CHO})$ cell-line, in triplicate on one occasion. The antiplasmodial and cytotoxicity assays were performed as described previously $[8,39,40]$.

The results from the biological study are summarized in Table 1. Although most of these compounds were shown to possess weak or no antiplasmodial activity, eight of them (i.e., compounds $6 \mathbf{a}, 9 \mathbf{9}, \mathbf{b}, \mathbf{1 5 c}, \mathbf{d}, \mathbf{1 6} \mathbf{a}, \mathbf{b}, \mathbf{f})$ were identified as potentially interesting for further study with $\mathrm{IC}_{50}$-values of $\leq 25 \mu \mathrm{M}$. Moreover, these compounds, with the exception of triamino-

\begin{tabular}{|c|c|c|c|c|c|c|c|c|}
\hline Compound & $\mathrm{R}^{1}$ & $\mathrm{R}^{2}$ & $\mathrm{R}^{3}$ & $\begin{array}{l}\text { D10: } \\
\text { IC }_{50}(\mu \mathrm{M})\end{array}$ & $\begin{array}{l}\mathrm{Dd} 2: \\
\mathrm{IC}_{50}(\mu \mathrm{M})\end{array}$ & $\begin{array}{l}\text { CHO: } \\
I_{50}(\mu \mathrm{M})\end{array}$ & $\mathrm{Rl}^{\mathrm{a}}$ & $s I^{b}$ \\
\hline $6 a$ & $4-\mathrm{Cl}$ & $\mathrm{Bn}$ & - & 12.58 & 10.88 & 137.90 & 0.9 & 11 \\
\hline $6 b$ & 4-OMe & $\mathrm{iBu}$ & - & 281.58 & ND & ND & ND & ND \\
\hline $6 c$ & $2-F$ & $n-\operatorname{Pr}$ & - & 217.34 & ND & ND & ND & ND \\
\hline $8 a$ & $\mathrm{H}$ & $\mathrm{iPr}$ & - & 369.70 & ND & ND & ND & ND \\
\hline $8 b$ & $\mathrm{H}$ & $\mathrm{Bn}$ & - & 143.79 & ND & ND & ND & ND \\
\hline $8 c$ & $4-\mathrm{Cl}$ & $\mathrm{Bn}$ & - & 198.56 & ND & ND & ND & ND \\
\hline $8 d$ & 4-OMe & $\mathrm{iBu}$ & - & 38.56 & 25.69 & $>530$ & 0.7 & ND \\
\hline $8 e$ & $2-F$ & $n-P r$ & - & 38.54 & 21.92 & $>530$ & 0.6 & ND \\
\hline $9 a$ & $4-\mathrm{Cl}$ & $\mathrm{Bn}$ & - & 25.22 & 8.47 & $>530$ & 0.3 & ND \\
\hline $9 b$ & $2-\mathrm{Cl}$ & $\mathrm{Bn}$ & - & 21.18 & 13.57 & $>530$ & 0.6 & ND \\
\hline $9 c$ & 4-Me & $\mathrm{Bn}$ & - & 129.86 & ND & ND & ND & ND \\
\hline $9 d$ & $\mathrm{H}$ & 4-CIBn & - & 80.68 & ND & ND & ND & ND \\
\hline $12 a$ & OMe & - & - & 98.68 & ND & ND & ND & ND \\
\hline $12 b$ & $\mathrm{~F}$ & - & - & 60.46 & ND & ND & ND & ND \\
\hline $14 a$ & $\mathrm{H}$ & - & - & 230.40 & 466.81 & $>530$ & 2 & ND \\
\hline $14 b$ & $4-\mathrm{Cl}$ & - & - & 100.82 & ND & ND & ND & ND \\
\hline $14 c$ & 4-OMe & - & - & 160.50 & ND & ND & ND & ND \\
\hline $14 d$ & $2-\mathrm{Cl}$ & - & - & 93.68 & ND & ND & ND & ND \\
\hline $14 e$ & $3-\mathrm{Cl}$ & - & - & 179.86 & ND & ND & ND & ND \\
\hline $15 a$ & $\mathrm{H}$ & $\mathrm{H}$ & - & 34.44 & 106.97 & $>530$ & 3.1 & ND \\
\hline $15 b$ & $4-\mathrm{Cl}$ & $\mathrm{H}$ & - & 41.32 & ND & ND & ND & ND \\
\hline $15 c$ & 4-OMe & $\mathrm{H}$ & - & 25.69 & 55.65 & $>530$ & 2.2 & ND \\
\hline $15 d$ & $\mathrm{H}$ & $\mathrm{Me}$ & - & 20.43 & 20.99 & $>530$ & 1 & ND \\
\hline $15 e$ & $\mathrm{H}$ & OMe & - & 40.54 & ND & ND & ND & ND \\
\hline $15 f$ & $2-\mathrm{Cl}$ & $\mathrm{H}$ & - & 32.33 & 25.00 & $>530$ & 0.8 & ND \\
\hline $16 a$ & $\mathrm{H}$ & $\mathrm{H}$ & Et & 22.09 & 231.47 & $>530$ & 10.5 & ND \\
\hline $16 b$ & $4-\mathrm{Cl}$ & $\mathrm{H}$ & $\mathrm{Et}$ & 25.86 & 176.40 & $>530$ & 6.8 & ND \\
\hline $16 c$ & 4-OMe & $\mathrm{H}$ & Et & 139.61 & ND & ND & ND & ND \\
\hline $16 d$ & $\mathrm{H}$ & $\mathrm{Me}$ & Et & 32.55 & ND & ND & ND & ND \\
\hline $16 e$ & $\mathrm{H}$ & OMe & $\mathrm{Et}$ & 171.37 & ND & ND & ND & ND \\
\hline $16 f$ & $2-\mathrm{Cl}$ & $\mathrm{H}$ & $\mathrm{Me}$ & 11.33 & 13.03 & 181.83 & 1.2 & 16.1 \\
\hline $16 \mathrm{~g}$ & $\mathrm{H}$ & $\mathrm{H}$ & $\mathrm{Me}$ & 69.58 & ND & ND & ND & ND \\
\hline $\mathrm{CQ}$ & & & & $\begin{array}{l}19.14 \mathrm{ng} / \mathrm{mL} \\
(n=6)\end{array}$ & $\begin{array}{l}75.56 \mathrm{ng} / \mathrm{mL} \\
(n=5)\end{array}$ & & 3.9 & \\
\hline Emetine & & & & & & $\begin{array}{l}0.27 \\
(n=6)\end{array}$ & & \\
\hline
\end{tabular}

aRI (Resistance Index) $=I C_{50}$ Dd2/IC ${ }_{50} \mathrm{D} 10 ;$ bSI (Selectivity Index) $=I C_{50} \mathrm{CHO} / / C_{50} \mathrm{D} 10 ; \mathrm{ND}=$ not determined; $n=$ number of data sets averaged. The more hydrophobic samples were added to the parasites as a suspension, meaning that for these samples the reported $\mathrm{IC}_{50}$-value might be an underestimation of the activity. 
propanes $16 \mathbf{a}, \mathbf{b}$, also proved to be active against a chloroquineresistant strain of $P$. falciparum (Dd2). In addition, the in vitro cytotoxicity results showed that only compounds $\mathbf{6 a}$ and $\mathbf{1 6 f}$ have lower selectivity with SI's of 11 and 16, respectively, whereas the other compounds did not show cytotoxicity at the concentrations tested.

Although the aziridine moiety was initially only considered as a synthetically useful entity, two 2-[(1,2,3-triazol-1-yl)methyl]aziridines (15c and 15d) were also found to exhibit weak antiplasmodial activity. On the other hand, the aminopropane unit has again proven its value as a template for the preparation of novel antimalarial agents, as a variety of structurally different aminopropanes were demonstrated to exhibit weak to moderate antiplasmodial activity. In particular, antiplasmodial assays against a chloroquine-sensitive strain of $P$. falciparum (D10) showed activity for 2-aminopropan-1-ol 6a, 2-aminopropan1,3-diols 9a,b and triaminopropanes $\mathbf{1 6 a}, \mathbf{b}, \mathbf{f}$ with $\mathrm{IC}_{50}$-values between 11.3 and $25.9 \mu \mathrm{M}$. Moreover, screening against a chloroquine-resistant strain of $P$. falciparum (Dd2) revealed antiplasmodial activity for 2-aminopropan-1-ol 6a, 2-aminopropan-1,3-diols $\mathbf{9 a}, \mathbf{b}$ and triaminopropane $\mathbf{1 6} \mathbf{f}$ with $\mathrm{IC}_{50^{-}}$ values between 8.5 and $13.6 \mu \mathrm{M}$.

From a structure-activity relationship viewpoint, the presence of a chlorinated aromatic ring seems to contribute to the antiplasmodial activity of these functionalized aminopropanes, and the introduction of a dimethylamino group at the expense of a diethylamino moiety might provide better activities in some cases. It is noteworthy that these compounds were synthesized in racemic form, and it is conceivable that enantiomerically pure variants could deliver superior activities. It should also be noted that, in general, the bioactivities reported in this paper are less pronounced as compared to those described in literature precedents on the synthesis and evaluation of functionalized aminopropanes $[6,8]$.

\section{Conclusion}

In summary, a variety of 2-amino-3-arylpropan-1-ols, anti-2amino-3-aryl-3-methoxypropan-1-ols and anti-2-amino-1-arylpropan-1,3-diols were prepared selectively through elaboration of trans-4-aryl-3-chloro- $\beta$-lactams. Furthermore, a number of 2-(azidomethyl)aziridines were converted into novel 2-[(1,2,3triazol-1-yl)methyl]aziridines by $\mathrm{Cu}(\mathrm{I})$-catalyzed azide-alkyne cycloaddition, followed by microwave-assisted, regioselective ring opening by diethyl- or dimethylamine towards the corresponding 1-(2,3-diaminopropyl)-1,2,3-triazoles. From a synthetic viewpoint, new insights were provided concerning the water-induced ring opening of nonactivated cis- and trans-2aryl-3-(hydroxymethyl)aziridines and with respect to the synthesis and use of 1-arylmethyl-2-(azidomethyl)aziridines for azide-alkyne cycloaddition reactions. From a biological viewpoint, most of these compounds exhibited weak antiplasmodial activity, although six representatives showed moderate antiplasmodial activity against both a chloroquine-sensitive and a chloroquine-resistant strain of $P$. falciparum with $\mathrm{IC}_{50}$-values of $\leq 25 \mu \mathrm{M}$.

\section{Experimental}

General information regarding NMR, IR, MS and elemental analyses, melting point measurements, and microwave reaction conditions can be found in the literature [8].

\section{anti-2-(N-Benzylamino)-1-(4-chlorophenyl)- propan-1,3-diol (9a)}

Recrystallization from hexane/EtOAc $(1: 25)$, white crystals, 95\%. Mp $192.3{ }^{\circ} \mathrm{C} ;{ }^{1} \mathrm{H}$ NMR (300 MHz, $\left.\mathrm{CDCl}_{3}\right) \delta 2.39(\mathrm{~s}, 2 \mathrm{H})$, $3.12-3.18(\mathrm{~m}, 1 \mathrm{H}), 3.54(\mathrm{dd}, J=13.0,3.6 \mathrm{~Hz}, 1 \mathrm{H}), 3.82(\mathrm{dd}$, $J=13.0,5.8 \mathrm{~Hz}, 1 \mathrm{H}), 4.27$ and $4.32(2 \mathrm{~d}, J=13.2 \mathrm{~Hz}, 2 \times 1 \mathrm{H})$, $5.24(\mathrm{~d}, J=2.2 \mathrm{~Hz}, 1 \mathrm{H}), 7.04-7.07,7.19-7.36,7.46-7.49$ and 7.69-7.71 (4 m, 2H, 3H, 2H, 2H); $\left.{ }^{13} \mathrm{C} \mathrm{NMR} \mathrm{(75} \mathrm{MHz,} \mathrm{CDCl}_{3}\right)$ $\delta 51.0,59.4,62.6,72.0,127.2,128.1,128.7,128.8,128.9$, 133.4, 137.0, 139.1; IR $\left(\mathrm{cm}^{-1}\right) v_{\max }: 3437(\mathrm{OH}), 3342(\mathrm{NH})$, 2926, 1448, 1162, 1008, 681; MS (70 eV) m/z (\%): 292/4 $\left(\mathrm{M}^{+}+1,100\right)$; HRMS (ESI): $[\mathrm{M}+\mathrm{H}]^{+}$calcd for $\mathrm{C}_{16} \mathrm{H}_{19} \mathrm{CINO}_{2}$, 292.1104; found, 292.1112.

\section{syn-2-(N-tert-Butylamino)-1-(2-methoxyphen- yl)propan-1,3-diol (12a)}

$R_{\mathrm{f}} 0.07$ (EtOAc), white crystals, $30 \%$. Mp $112.8{ }^{\circ} \mathrm{C} ;{ }^{1} \mathrm{H}$ NMR $\left(300 \mathrm{MHz}, \mathrm{CDCl}_{3}\right) \delta 1.03(\mathrm{~s}, 9 \mathrm{H}), 2.77$ (ddd, $J=7.1,3.0$, $3.0 \mathrm{~Hz}, 1 \mathrm{H}), 3.50-3.51(\mathrm{~m}, 2 \mathrm{H}), 3.86(\mathrm{~s}, 3 \mathrm{H}), 4.80(\mathrm{~d}, J=$ $7.1 \mathrm{~Hz}, 1 \mathrm{H}), 6.87-6.89,6.98-7.03,7.22-7.28$ and 7.47-7.50 $(4 \mathrm{~m}, 4 \times 1 \mathrm{H}) ;{ }^{13} \mathrm{C} \mathrm{NMR}\left(75 \mathrm{MHz}, \mathrm{CDCl}_{3}\right) \delta 30.0,50.8,55.6$, $58.1,63.7,68.5,110.4,121.3,127.7,128.4,130.5,156.5$; IR $\left(\mathrm{cm}^{-1}\right) v_{\max }: 3391(\mathrm{NH}), 3313(\mathrm{OH}), 3058,3004,2987,2957$, 2927, 2873, 2838, 1492, 1467, 1438, 1368, 1242, 1066, 1050, 1027, 755; MS (70 eV) m/z (\%): $254\left(\mathrm{M}^{+}+1,100\right)$; HRMS (ESI): $[\mathrm{M}+\mathrm{H}]^{+}$calcd for $\mathrm{C}_{14} \mathrm{H}_{24} \mathrm{NO}_{3}, 254.1756$; found, 254.1766 .

\section{2-Azidomethyl-1-(phenylmethyl)aziridine}

\section{(14a)}

$R_{\mathrm{f}} 0.20$ (hexane/EtOAc $4: 1$ ), yellow oil, $70 \%$. ${ }^{1} \mathrm{H}$ NMR $\left(300 \mathrm{MHz}, \mathrm{CDCl}_{3}\right) \delta 1.51(\mathrm{~d}, J=6.1 \mathrm{~Hz}, 1 \mathrm{H}), 1.79(\mathrm{~d}, J=$ $3.3 \mathrm{~Hz}, 1 \mathrm{H}), 1.79-1.86(\mathrm{~m}, 1 \mathrm{H}), 3.18$ and $3.27(2 \mathrm{dd}, J=12.9$, 6.6, 4.4 Hz, 2H) 3.38 and $3.58(2 \mathrm{~d}, J=13.2 \mathrm{~Hz}, 2 \mathrm{H}), 7.24-7.36$ $(\mathrm{m}, 5 \mathrm{H}) ;{ }^{13} \mathrm{C} \mathrm{NMR}\left(75 \mathrm{MHz}, \mathrm{CDCl}_{3}\right) \delta 32.2,37.9,53.8,64.3$, 127.4, 128.3, 128.6, 138.8; IR (cm $\left.{ }^{-1}\right) v_{\max }: 2088\left(\mathrm{~N}_{3}\right), 1453$, 1357, 1322, 1255, 1159, 1062, 1028, 907, 732, 697; MS $(70 \mathrm{eV}) \mathrm{m} / z(\%): 189\left(\mathrm{M}^{+}+1,100\right)$; HRMS (ESI): $[\mathrm{M}+\mathrm{H}]^{+}$ calcd for $\mathrm{C}_{10} \mathrm{H}_{13} \mathrm{~N}_{4}, 189.1140$; found, 189.1141. 
1-Phenylmethyl-2-[(4-phenyl-1,2,3-triazol-1yl)methyl]aziridine (15a)

$R_{\mathrm{f}} 0.23\left(\mathrm{CHCl}_{3} / \mathrm{MeOH} 98: 2\right)$, viscous light-brown oil, $61 \%$. ${ }^{1} \mathrm{H} \mathrm{NMR}\left(300 \mathrm{MHz}, \mathrm{CDCl}_{3}\right) \delta 1.65(\mathrm{~d}, J=6.6 \mathrm{~Hz}, 1 \mathrm{H}), 1.88(\mathrm{~d}$, $J=3.3 \mathrm{~Hz}, 1 \mathrm{H}), 2.01-2.08(\mathrm{~m}, 1 \mathrm{H}), 3.09$ and $3.67(2 \mathrm{~d}, J=$ $12.9 \mathrm{~Hz}, 2 \mathrm{H}), 3.93$ and $4.70(2 \mathrm{dd}, J=14.3,8.2,3.3 \mathrm{~Hz}, 2 \mathrm{H})$, 7.06-7.43 (m, 8H), 7.49 (s, 1H), 7.66-7.69 (m, 2H); ${ }^{13} \mathrm{C}$ NMR $\left(75 \mathrm{MHz}, \mathrm{CDCl}_{3}\right) \delta 32.4,38.3,53.5,64.5,119.9,125.9,127.7$, 128.1, 128.4, 128.6, 128.7, 130.8, 138.2, 147.9; IR $\left(\mathrm{cm}^{-1}\right) v_{\max }$ : 2919, 1453, 1358, 1225, 1075, 1046, 1027, 763, 731, 694; MS $(70 \mathrm{eV}) \mathrm{m} / z(\%): 291\left(\mathrm{M}^{+}+1,100\right)$; HRMS (ESI): $[\mathrm{M}+\mathrm{H}]^{+}$ calcd for $\mathrm{C}_{18} \mathrm{H}_{19} \mathrm{~N}_{4}, 291.1610$; found, 291.1613.

\section{3-Diethylamino-2-(phenylmethyl)amino-1-(4- phenyl-1,2,3-triazol-1-yl)propane (16a)}

$R_{\mathrm{f}} 0.19\left(\mathrm{CHCl}_{3} / \mathrm{MeOH}\right.$ 97:3), light-brown oil, 56\%. ${ }^{1} \mathrm{H}$ NMR $\left(300 \mathrm{MHz}, \mathrm{CDCl}_{3}\right) \delta 0.92(\mathrm{t}, J=7.2 \mathrm{~Hz}, 6 \mathrm{H}), 2.26-2.52(\mathrm{~m}$, $6 \mathrm{H}), 3.05-3.13(\mathrm{~m}, 1 \mathrm{H}), 3.74$ and $3.81(2 \mathrm{~d}, J=13.5 \mathrm{~Hz}, 2 \mathrm{H})$, 4.36 and $4.44(2 \mathrm{dd}, J=14.2,4.9,4.7 \mathrm{~Hz}, 2 \mathrm{H}), 7.21-7.44$ and $7.82-7.84(2 \mathrm{~m}, 10 \mathrm{H}), 7.86(\mathrm{~s}, 1 \mathrm{H}) ;{ }^{13} \mathrm{C} \mathrm{NMR}(75 \mathrm{MHz}$, $\left.\mathrm{CDCl}_{3}\right) \delta 11.8,47.1,52.0,52.3,55.0,55.4,121.2,125.8,127.2$, 128.1, 128.2, 128.6, 128.9, 130.9, 140.2, 147.5; IR (cm $\left.{ }^{-1}\right) v_{\max }$ : 2967, 1462, 1454, 1073, 762, 734, 694; MS (70 eV) $\mathrm{m} / z(\%)$ : $364\left(\mathrm{M}^{+}+1,100\right)$; HRMS (ESI): $[\mathrm{M}+\mathrm{H}]^{+}$calcd for $\mathrm{C}_{22} \mathrm{H}_{30} \mathrm{~N}_{5}, 364.2501$; found, 364.2503.

\section{Supporting Information}

\section{Supporting Information File 1}

Experimental procedures and characterization data. [http://www.beilstein-journals.org/bjoc/content/ supplementary/1860-5397-7-205-S1.pdf]

\section{Acknowledgements}

The authors are indebted to the "Research Foundation - Flanders" (FWO-Vlaanderen), the "Institute for the Promotion of Innovation through Science and Technology - Flanders" (IWTVlaanderen), and to Ghent University (GOA) for financial support.

\section{References}

1. WHO Fact sheet on malaria $N^{\circ} 94$, January 2009.

2. Gemma, S.; Travagli, V.; Savini, L.; Novellino, E.; Campiani, G.; Butini, S. Recent Pat. Antiinfect. Drug. Discov. 2010, 5, 195.

3. Robin, A.; Brown, F.; Bahamontes-Rosa, N.; Wu, B.; Beitz, E.; Kun, J. F. J.; Flitsch, S. L. J. Med. Chem. 2007, 50, 4243. doi:10.1021/jm070553।

4. Murphy, S. C.; Harrison, T.; Hamm, H. E.; Lomasney, J. W.; Mohandas, N.; Haldar, K. PLoS Med. 2006, 3, 2403. doi:10.1371/journal.pmed.0030528
5. Harrison, T.; Samuel, B. U.; Akompong, T.; Hamm, H.; Mohandas, N.; Lomasney, J. W.; Haldar, K. Science 2003, 301, 1734. doi:10.1126/science.1089324

6. D'hooghe, M.; Dekeukeleire, S.; Mollet, K.; Lategan, C.; Smith, P. J.; Chibale, K.; De Kimpe, N. J. Med. Chem. 2009, 52, 4058. doi:10.1021/jm9002632

7. Pérez-Silanes, S.; Berrade, L.; García-Sánchez, R. N.; Mendoza, A.; Galiano, S.; Pérez-Solórzano, B. M.; Nogal-Ruiz, J. J.; Martínez-Fernández, A. R.; Aldana, I.; Monge, A. Molecules 2009, 14, 4120. doi:10.3390/molecules14104120

8. D’hooghe, M.; Kenis, S.; Vervisch, K.; Lategan, C.; Smith, P. J.; Chibale, K.; De Kimpe, N. Eur. J. Med. Chem. 2011, 46, 579. doi:10.1016/j.ejmech.2010.11.037

9. Zwanenburg, B.; ten Holte, P. Top. Curr. Chem. 2001, 216, 93. doi:10.1007/3-540-44726-1_3

10. Sweeney, J. B. Chem. Soc. Rev. 2002, 31, 247. doi:10.1039/b006015। 11. Hu, X. E. Tetrahedron 2004, 60, 2701. doi:10.1016/j.tet.2004.01.042

12. Tanner, D. Angew. Chem., Int. Ed. Engl. 1994, 33, 599. doi:10.1002/anie.199405991

13. Osborn, H. M. I.; Sweeney, J. Tetrahedron: Asymmetry 1997, 8, 1693. doi:10.1016/S0957-4166(97)00177-8

14. McCoull, W. M.; Davis, F. A. Synthesis 2000, 1347. doi:10.1055/s-2000-7097

15. Watson, I. D. G.; Yu, L.; Yudin, A. K. Acc. Chem. Res. 2006, 39, 194. doi:10.1021/ar050038m

16. Padwa, A.; Murphree, S. S. ARKIVOC 2006, No. iii, 6.

17. Singh, G. S.; D'hooghe, M.; De Kimpe, N. Chem. Rev. 2007, 107, 2080. doi:10.1021/cr0680033

18. Ojima, I.; Delaloge, F. Chem. Soc. Rev. 1997, 26, 377. doi:10.1039/cs9972600377

19. Alcaide, B.; Almendros, P. Synlett 2002, 381. doi:10.1055/s-2002-20448

20. Fisher, J. F.; Meroueh, S. O.; Mobashery, S. Chem. Rev. 2005, 105, 395. doi:10.1021/cr030102i

21. Alcaide, B.; Almendros, P.; Aragoncillo, C. Chem. Rev. 2007, 107, 4437. doi:10.1021/cr0307300

22. Ojima, I. Acc. Chem. Res. 1995, 28, 383. doi:10.1021/ar00057a004

23. Singh, G. S. Tetrahedron 2003, 59, 7631. doi:10.1016/S0040-4020(03)01099-8

24. Singh, G. S.; D'hooghe, M.; De Kimpe, N. In Comprehensive Heterocyclic Chemistry III; Katritzky, A.; Ramsden, C.; Scriven, E.; Taylor, R., Eds.; Elsevier: Oxford, 2008; Vol. 2, p 1. doi:10.1016/B978-008044992-0.00201-7

25. Xing, B.; Rao, J.; Liu, R. Mini-Rev. Med. Chem. 2008, 8, 455. doi:10.2174/138955708784223558

26. Aranda, M. T.; Perez-Faginas, P.; Gonzalez-Muniz, R. Curr. Org. Synth. 2009, 6, 325. doi:10.2174/157017909788921899

27. D'hooghe, M.; Dekeukeleire, S.; Leemans, E.; De Kimpe, N. Pure Appl. Chem. 2010, 82, 1749. doi:10.1351/PAC-CON-09-09-39

28. Van Driessche, B.; Van Brabandt, W.; D'hooghe, M.; Dejaegher, Y.; De Kimpe, N. Tetrahedron 2006, 62, 6882. doi:10.1016/j.tet.2006.04.104

29. D'hooghe, M.; Dekeukeleire, S.; De Kimpe, N. Org. Biomol. Chem. 2008, 6, 1190. doi:10.1039/b719686e

30. D'hooghe, M.; Mollet, K.; Dekeukeleire, S.; De Kimpe, N. Org. Biomol. Chem. 2010, 8, 607. doi:10.1039/b919864d

31. Mollet, K.; D’hooghe, M.; De Kimpe, N. J. Org. Chem. 2011, 76, 264. doi:10.1021/jo1020932 
32. Manaka, T.; Nagayama, S.-I.; Desadee, W.; Yajima, N.; Kumamoto, T.; Watanabe, T.; Ishikawa, T.; Kawahata, M.; Yamaguchi, K. Helv. Chim. Acta 2007, 90, 128. doi:10.1002/hlca.200790006

33. Hein, J. E.; Fokin, V. V. Chem. Soc. Rev. 2010, 39, 1302. doi:10.1039/b904091a

34. Kolb, H. C.; Finn, M. G.; Sharpless, K. B. Angew. Chem., Int. Ed. 2001, 40, 2004.

doi:10.1002/1521-3773(20010601)40:11<2004::AID-ANIE2004>3.0.CO ;2-5

35. Jamookeeah, C. E.; Beadle, C. D.; Harrity, J. P. A. Synthesis 2009 , 133. doi:10.1055/s-0028-1083270

36. De Kimpe, N.; Jolie, R.; De Smaele, D. J. Chem. Soc., Chem. Commun. 1994, 1221. doi:10.1039/C39940001221

37. D'hooghe, M.; Waterinckx, A.; Kimpe, N. J. Org. Chem. 2005, 70, 227. doi:10.1021/jo048486f

38. D'hooghe, M.; Rottiers, M.; Jolie, R.; De Kimpe, N. Synlett 2005, 931. doi:10.1055/s-2005-864801

39. Kamdem Waffo, A. F.; Coombes, P. H.; Crouch, N. R.; Mulholland, D. A.; El Amin, S. M. M.; Smith, P. J. Phytochemistry 2007, 68, 663. doi:10.1016/j.phytochem.2006.10.011

40. Khanye, S. D.; Smith, G. S.; Lategan, C.; Smith, P. J.; Gut, J.; Rosenthal, P. J.; Chibale, K. J. Inorg. Biochem. 2010, 104, 1079. doi:10.1016/j.jinorgbio.2010.06.005

\section{License and Terms}

This is an Open Access article under the terms of the Creative Commons Attribution License

(http://creativecommons.org/licenses/by/2.0), which permits unrestricted use, distribution, and reproduction in any medium, provided the original work is properly cited.

The license is subject to the Beilstein Journal of Organic Chemistry terms and conditions:

(http://www.beilstein-journals.org/bjoc)

The definitive version of this article is the electronic one which can be found at: doi:10.3762/bjoc.7.205 